\title{
"To dispose of wealth in works of charity": entrepreneurship and philanthropy in Medieval England
}

Article

Accepted Version

Casson, C. and Casson, M. (2019) "To dispose of wealth in works of charity": entrepreneurship and philanthropy in Medieval England. Business History Review, 93 (3). pp. 473502. ISSN 2044-768X doi:

https://doi.org/10.1017/S0007680519000874 Available at https://centaur.reading.ac.uk/81898/

It is advisable to refer to the publisher's version if you intend to cite from the work. See Guidance on citing.

To link to this article DOI: http://dx.doi.org/10.1017/S0007680519000874

Publisher: Cambridge University Press

All outputs in CentAUR are protected by Intellectual Property Rights law, including copyright law. Copyright and IPR is retained by the creators or other copyright holders. Terms and conditions for use of this material are defined in the End User Agreement.

www.reading.ac.uk/centaur 
Central Archive at the University of Reading

Reading's research outputs online 


\title{
"To Dispose of Wealth in Works of Charity": Entrepreneurship and Philanthropy in Medieval England
}

\author{
Catherine Casson (Alliance Manchester Business School, University of \\ Manchester) and Mark Casson (Department of Economics, University of \\ Reading)
}

\begin{abstract}
While entrepreneurs are increasingly recognized as important participants in the medieval economy, their philanthropic activities have received less attention compared to those of the gentry and nobility. This article shows the contribution that the study of medieval entrepreneurs can make to broader business history debates surrounding the identity of philanthropists and their beneficiaries, the types of causes they supported, and their impact on wider society. Philanthropic entrepreneurs used the profits of commerce to provide infrastructure, healthcare, and education to their local communities. Their patterns of philanthropy differed from those of gentry, lawyers, and administrators. Support for municipal infrastructure emerges as a distinctive feature of entrepreneurial philanthropy, reflecting a belief in the importance of trade networks and civic reputation.
\end{abstract}

Keywords: entrepreneur; merchant; philanthropy; charity; welfare; medieval 


\section{"To Dispose of Wealth in Works of Charity": Entrepreneurship and Philanthropy in Medieval England}

\section{Introduction}

Entrepreneurs in the middle ages invested the profits of commerce in infrastructure, healthcare, and education for the wider community. Such support boosted economic performance by strengthening the knowledge economy, improving access to markets, and aiding worker productivity. The philanthropy of entrepreneurs complemented the activities of religious institutions and subscription guilds, which have been the focus of much existing research. Entrepreneurs, the evidence shows, engaged in philanthropy to a greater extent than other professions, and exhibited distinctive patterns of giving.

England in the middle ages experienced a commercial revolution often seen as a precursor to the Industrial Revolution. Urbanization intensified through an expansion in the number of towns and in the size of existing towns; new urban institutions emerged to regulate trade while the quantity and quality of manufactured products increased. A service sector of scribal and legal services supported merchants in their interactions with each other and with local and central government, and provided careers for lawyers and administrators. In the countryside, landlords experimented with new cultivation techniques, exploited the natural mineral resources of their landed estates and grazed sheep for the wool trade. England's wool production and strong currency, together with long-distance distribution networks, encouraged overseas trade with the Continent.

Entrepreneurial individuals seized the business opportunities that resulted from commercialization. Opportunities were particularly prevalent in towns, where settlement was encouraged through the provision of infrastructure, institutions, markets, and the ability to buy and sell property. Urban merchants operated owner-managed businesses, or partnerships with family, friends, and trusted business contacts. In rural areas property ownership was concentrated on a knightly class of rural manorial lords, controlling local peasants who possessed varying degrees of self-autonomy.

While entrepreneurs are increasingly recognized as important participants in the medieval economy, their philanthropic activities in the middle ages have received less attention 
compared to those of the gentry and nobility. ${ }^{1}$ Business history scholarship on philanthropy, meanwhile, has focused on the nineteenth and twentieth centuries rather than the medieval period. This paper redresses these imbalances. For the purposes of this paper an entrepreneur is defined as an individual whose main source of income is profit and who has demonstrated initiative and good judgement in their business dealings. The analysis focuses on successful entrepreneurs who became wealthy through their own initiative, or by building on the achievements of others. It includes both the founders of firms and second-generation entrepreneurs who grew existing businesses by taking advantage of opportunities they discovered for themselves. The analysis therefore allows for the fact that some of the entrepreneur's wealth may have been inherited rather than earned. We focus on entrepreneurs who died between 1300 and $1500 .^{2}$

The article examines philanthropy effected through the foundation, endowment, or support of charitable institutions that benefitted the public as a whole, rather than just family and friends. Gifts could be in money or in kind, or a mixture of the two (e.g. a building together with a financial endowment to support its running expenses). The focus is on the causes supported by philanthropists. ${ }^{3}$

Philanthropy by entrepreneurs has been considered from a range of disciplinary perspectives and across a number of chronological periods. There are many approaches to philanthropy, including organizational ones, but given the limited development of business organizations in the middle ages, an individual approach is used in this study. ${ }^{4}$

History scholarship debates whether attitudes to philanthropy were altered by the English Reformation of c. 1530-1547. Jordan, using evidence from English wills of 1480-1660, suggested that the Reformation transformed the social attitudes of philanthropists from spiritual (support for religion) to secular (support for the poor). ${ }^{5}$ Burgess, drawing on wills from fifteenth-century Bristol, suggested that the Reformation's removal of "belief in and provision for" Purgatory reduced the level of philanthropic support by members of the laity for their local parish. ${ }^{6}$ The connection between philanthropy and religion was undoubtedly close during the middle ages. Rosenthal concludes from wills and alienations in mortmain that, in the fourteenth and fifteenth centuries, English nobles were primarily motivated by the desire to obtain prayers from recipients of gifts. ${ }^{7}$ Jordan sought to nuance the concept of philanthropic motivation by creating categories of "poor relief, social rehabilitation, municipal betterments, education, and religion."

Social scientists and business historians have also formulated research questions relating to motivation, drawing primarily on evidence from the nineteenth and twentieth 
centuries. ${ }^{9}$ There are indications that entrepreneurs exhibit distinctive patterns of philanthropy because they identify opportunities for giving during their careers and apply skills developed in business to philanthropic activities. ${ }^{10}$ It has been suggested that entrepreneurs have displayed a particular interest in supporting "disadvantaged" groups, their employees, members of their community of origin and, more generally, promoting enterprise development and education. Mechanisms that encourage philanthropy have been examined. ${ }^{11}$ Evidence suggests that philanthropic entrepreneurs value both the benefits conferred on the recipients, and the enhanced status accorded to the donor. ${ }^{12}$

This article first examines the types of philanthropy in which entrepreneurs engaged. It then considers whether entrepreneurs supported different types of philanthropy compared to members of other occupations. Finally, the paper compares philanthropy with alternative uses of personal wealth.

\section{Methodology}

Inspired by Jeremy's study of business leaders and the church in twentieth-century Britain, a multi-stage process was followed. ${ }^{13}$ The first step was to create a typology of philanthropy suitable for the medieval period. This step does two things: it distinguishes the different uses of philanthropic resources, and separates philanthropic uses from nonphilanthropic uses. The objects of philanthropy are classified as the poor, the young, relief of prisoners, support for employees, social rehabilitation, almshouses, other personal charity, municipal improvements, education, and religion (Table 1). Non-philanthropic uses of resources are categorized in Table 2.

The second step was to identify key sources from which a sample of medieval entrepreneurs could be compiled. Business archives rarely survive for the middle ages but the activities of entrepreneurs can be traced from other sources. These include Oxford Dictionary of National Biography [ODNB], History of Parliament (several entrepreneurs were MPs), biographies of famous figures, such as Richard Whittington, and histories of medieval towns. This methodology enabled entrepreneurs to be identified without restricting the sample to civic office holders, guild members or men.

Beginning with the $O D N B$, a key word search was conducted for 'entrepreneur,' 'merchant,' and 'trader' in the full text field of the online edition. Anyone who operated wholly outside of England, who died outside of our chronological period, or did not meet our definition 
of an entrepreneur, was excluded. A pool of seventy-one entrepreneurs was generated. Fortythree were then excluded as they did not meet our definition of philanthropy, leaving a pool of twenty eight. ${ }^{14}$ The problem of bias in sample selection is always present when dealing with medieval England and care must be taken drawing inferences on the basis of relatively small observed differences.

The use of the $O D N B$ may introduce a bias in favor of philanthropy if individuals are included as a result of their fame from philanthropy rather than because of their business activities. The second stage of our methodology was to use additional sources to eliminate source bias and increase our range of observations. ${ }^{15}$ This produced a further sixteen people and significantly enhanced the geographical scope of the study.

The third step involved a validation process in which additional information on each of the forty-four entrepreneurs was collected from primary sources such as wills, licences to alienate lands, guild records, civic records, and the records of charities. For each individual, data was collected on dates of birth and death, residence (birth place and subsequent residence if provided), gender, occupation, position as civic office holder (mayor, sheriff, alderman, recorder or bailiff), other family members, philanthropic activities, and alternative uses of wealth. Material culture and literary sources provided insights into the commemoration of philanthropy by subsequent generations.

A distinction was made between bequests during the philanthropist's lifetime and those made after their death. The former involved greater self-sacrifice on the part of the philanthropist, while the latter impacted surviving relatives to a greater extent. We recorded instances where the philanthropist was childless or had heirs they appear to have disinherited.

Finally, two dimensions of comparison were introduced: between philanthropists and non-philanthropists, and between philanthropy undertaken by different occupational groups. A comprehensive comparative study involving all recorded non-philanthropic medieval entrepreneurs is beyond the scope of this paper, but a more limited study can be carried out based on the $O D N B$ alone. For this purpose we identified all medieval lawyers, administrators, and gentry listed in the $O D N B$, classified them as philanthropic or non-philanthropic and recorded the causes supported by the philanthropists. The results are summarized in Table 3.

\section{Context to philanthropy in medieval England}


Philanthropy by entrepreneurs existed alongside, and often in co-operation with, other forms of welfare provision. Religious institutions funded their activities through donations, including land, moveable property and cash, and were important providers of health care and education. ${ }^{16}$ Guilds operated on a subscription model, with membership fees funding funeral services and welfare support for sick members and the families of deceased members. ${ }^{17}$ Occasionally guilds also supported infrastructure and education projects that benefitted the wider community. Local government used tolls, rents, and other sources of income to fund communal infrastructure (including market places, roads, bridges, and walls), maintain law and order, and support vulnerable groups such as orphans. Although royalty were important patrons of abbeys and the church, the royal exchequer (i.e. central government) rarely provided welfare support during this period, partly because there was not yet a system of regular taxation in place to fund it.

Religious teachings and the responsibilities of citizenship provided interconnected spiritual and secular incentives for philanthropy. ${ }^{18}$ A place in heaven could be obtained with greater ease and speed by engaging in the Seven Corporal Acts of Mercy of feeding the hungry, giving drink to the thirsty, visiting the sick, visiting prisoners, clothing the naked, sheltering the homeless (also sometimes known as receiving the stranger), and burying the dead. ${ }^{19}$ Recipients could show their gratitude by praying for the soul of the donor, thus reducing the donor's time in purgatory. Reputable merchants also supported their civic communities by trading honestly (for example, by using fair weights and measures), maintaining reasonable prices (not seeking to profit from forestalling, regretting, or other forms of monopoly or speculation), and respecting the assays of bread and ale. ${ }^{20}$ Reputation gained in this way could be reinforced through acts of civic philanthropy. ${ }^{21}$

\section{Characteristics of philanthropic entrepreneurs}

The entrepreneurs in our sample pursued varied careers: some were mobile, seeking fame and fortune in big cities, but others chose to remain in their birthplace. Ten of the fortyfour entrepreneurs originated in London, and all remained there (see Table 4, top line). Thirtyone entrepreneurs originated in English provincial towns, of whom fifteen moved to London and sixteen remained in the provinces, with twelve staying in the town where they were born (Table 4, second line). The four that moved all made a short journey from their place of birth to the nearest major port. Three entrepreneurs migrated from overseas - two from Italy and one 
from North-West Germany. Thus while almost half the provincial-born entrepreneurs moved to London, none of the London entrepreneurs moved to the provinces. Altogether twenty-two entrepreneurs moved and twenty-two stayed.

Entrepreneurs supported causes connected to communities in which they lived and worked. Support for their birthplace was common. Of those who relocated, twelve supported their career-base destination, but three supported only their birthplace and seven supported both. Hugh Clopton, for example, supported his birthplace of Stratford-upon-Avon, despite moving to London, by funding dowries for two hundred poor local maidens, constructing a stone bridge, and repairing bridges and roads within a 10 mile radius. ${ }^{22}$ Richard Russell of York made a bequest "to repay" Durham Priory "fully for the board and lodging I had there in my youth." ${ }^{23}$ John Welles III, who moved to London, left 100 shillings for the upkeep of St George Muspole's church, Norwich "in whose holy font I was baptised," as well as bequests to London causes. $^{24}$ Three entrepreneurs favored their birthplace entirely over their destination, as exemplified by Tidemann Lemberg who migrated to London from North-West Germany and bequeathed money to religious foundations in Cologne, where he lived from 1352-1359 and again from 1363 until his death. ${ }^{25}$

Medieval entrepreneurs used social networks both to accumulate and dispose of their wealth. Nine per cent of philanthropic entrepreneurs are reported as having acquired capital from their wife. Drew Barantyn's first marriage to the widow of Sir Nicholas Twyford, undoubtedly aided him in accumulating a fortune that was by 1412 worth more than that of Whittington's and the Goldsmith's company, of which he was a member. ${ }^{26}$ He invested in an attractive property in London and properties in Oxfordshire, Cambridgeshire, Suffolk, and Buckinghamshire and, at his death, left money for to the poor of the parish of St John Zachery along with substantial bequests to his guild and to family members.

There are indications of the cross-fertilisation of practices amongst members of the same social and trading networks. In London Robert Chichele, Thomas Knolles, Richard Whittington, and William Sevenoak networked together, while Knolles was executor for John Welles III. York's Richard Russell was executor of Blackburn's will while Agnes Forster's husband had connections with Bristol's Canynges family via the shipping trade. ${ }^{27}$

There is some evidence that absence of descendants or unsuitable heirs motivated philanthropy. Twenty per cent of entrepreneurs had no children, including Whittington and William Canynges (Table 5). ${ }^{28}$ Others had children but chose to disinherit them. Russell's daughter married well and so did not need to be provided for in his will. ${ }^{29}$ Welles III had no biological children and disliked his stepson William Osbarn, specifying that any legacies to 
William should be made "null and void" if he harassed, defrauded or tricked the executors in any way. ${ }^{30}$ Simon Eyre had a troublesome son who was often imprisoned for debt. ${ }^{31}$

Civic office holding connected an entrepreneur's personal and professional lives and was a characteristic of sixty-six per cent of our sample. Civic office holders were more inclined to support the young, social rehabilitation, almshouses, municipal improvements, and education, while support for the poor, for prisoners, and for hospitals and healthcare was slightly more common amongst non-civic office holders. John Welles III and Stephen Brown exemplify civic officeholders who funded projects to fill gaps in local services. Welles III left legacies to a range of causes, including improvements to a water conduit and "a new boundary marker for my ward of West Cheap." 32 Brown, meanwhile, imported grain during his mayoralty to alleviate the 1438-1439 famine in London. ${ }^{33}$ Personal projects from a term of office could be completed by philanthropy. Forster finished her husband's initiative to rebuild and reform Newgate prison, which had burnt down during his mayoralty. ${ }^{34}$ Eyre contributed to the redevelopment of the Leadenhall market during his mayoralty, funding some of its construction directly, and bequeathing money to complete his plans. ${ }^{35}$

\section{Types of philanthropy}

\subsection{Municipal infrastructure}

We next examine the causes supported by the entrepreneurs. Bequests to road and bridge repairs reflected the importance of internal trading connections. ${ }^{36}$ Eastfield's use of inland trade routes may explain his decision to bequeath money for repairs to Wallingford bridge at his death in c. $1446 .{ }^{37}$ The timing of the bequest corresponds with a period of decline in Wallingford, attributed to the construction of a bridge at Abingdon by local philanthropic entrepreneurs in 1415-1416. ${ }^{38}$ Other entrepreneurs supported infrastructure that encouraged merchants to visit their home town, and helped their colleagues connect with the wider world. Nicholas Blackburn left bequests for repairs to four York bridges while Alice Chestre, who ran a Bristol export business, funded the construction of a new crane for both local and foreign merchants, the tolls from which went to support the town's finances. ${ }^{39}$

Water was used for industrial and domestic purposes and businesses were often accused of polluting and excessively using supplies during their production processes. ${ }^{40}$ Monastic houses sometimes allowed civic authorities to utilize conduits they had constructed, but entrepreneurial initiative also helped mitigate problems. ${ }^{41}$ Four entrepreneurs, Richard 
Whittington, William Eastfield, and John Welles III in London, and William Wilford in Exeter, funded fountains and conduits. ${ }^{42}$ Town walls were defensive barriers and toll collection points and were supported by John Crosbie (London) and Willam Soper (Southampton). ${ }^{43}$ Southampton's local government was so grateful for Soper's repairs to Watergate, which led from the quay to the town centre, that in 1433 they gave him a hundred year lease on its towers at a token rent and permission to construct a shop nearby. ${ }^{44}$

\subsection{Religion}

Entrepreneurs came into contact with monasteries through their business dealings and land transactions. William Walworth, an important wool trader with family links in Durham, remitted in his will a debt of 100 marks owed to him by Durham Priory, while John Crosby made a bequest to St Helen's Priory, which owned the land in Bishopgate Street, on which he had built an impressive house. ${ }^{45}$ Smaller bequests were more usual, such as that of London pepperer William de Thorneye to the abbot of Thorney (possibly his birthplace) and to the poor living in the abbey and on the surrounding dairy farms. ${ }^{46}$ Roger Thornton of Newcastle supported St Michael's Priory, near his house and recently founded by another citizen, and houses across North-East England, including Durham Minster whose lead mines he rented. ${ }^{47}$

Support for parish churches reflected the ties between philanthropic entrepreneurs and their local community. Four members of our sample - Roesia Burford, Robert Chichele, John Hawley, and John Pulteney - founded churches. Chichele donated land in 1428 to the parish of St Stephen Walbrok for the construction of a church and churchyard and in 1429 gave an additional $£ 100$ towards its construction. ${ }^{48}$ Chichele lived in the parish when he arrived in London and his brother Henry (archbishop of Canterbury and founder of All Souls College Oxford) had been rector there. John Pyel, a London wool and grain merchant and financier, established in his will a college for secular canons in the church of St Peter at his birthplace of Irthlingborough, Northamptonshire. ${ }^{49}$ Existing churches were also expanded and decorated. John Tame used his profits from the wool trade to rebuild St Mary's Church in Fairford in the fashionable Perpendicular style from the 1490s onwards, while John Lovekyn funded the rebuilding of St Michael, Crooked Lane, London. ${ }^{50}$

\subsection{Almshouses and Hospitals}

Almshouse foundation was more popular than religious house foundation and undertaken by four entrepreneurs. Donors benefited from recipients performing elements of the Corporal Acts and by receiving prayers for their soul while vulnerable members of the 
population received accommodation. Surviving rules drawn up in 1424 by Richard Whittington's executors for his foundation, for example, specified that residents should pray when rising and retiring, in church services, and in any spare moments for the souls of Whittington and his wife, their parents, and deceased and living members of the royal family. ${ }^{51}$

Hospitals were founded by Henry Tangmere in Cambridge and Roger Thornton in Newcastle. ${ }^{52}$ Thornton's foundation of St Katherine's was founded in 1402-1403 to 1412 and continued to be supported and integrated into communal life by his descendants. In 1456 Roger Thornton II permitted the local authorities to make the hospital's hall and kitchen available to newly-weds for their wedding meal, and from 1480 the facilities were used by the merchant adventurers for their court. ${ }^{53}$ Existing hospitals were supported by Richard Buckland, Matilda Penne, and Thomas Knolles, with Knolles bequeathing a shop near to existing property owned by the hospital of St Antholin. ${ }^{54}$

\subsection{Education}

Education became increasingly important for a career in business as the middle ages progressed and a written culture replaced an oral one. School foundation was successfully undertaken by William Sevenoak, and less successfully by the executors of Simon Eyre. ${ }^{55}$ During his mayoralty Eyre had added a school and chapel to the new granary under construction at Leadenhall, and appointed teachers of "Latin grammar, writing, and song." 56 The intention was probably to create an equivalent to the royal foundation at Eton, but resistance or lack of funds meant that the endeavour was halted and replaced with a chantry chapel. Tangmere donated houses and land to Corpus Christi College, founded by the town's Guild. ${ }^{57}$ In return, Tangmere expected the college to educate his son and arrange daily prayers for his soul and those of his family. Richard Andrew, also of Cambridge, made substantial cash bequests to Queen's College in return for prayers for his soul. ${ }^{58}$ Donations to the London Guildhall and Cambridge University library were made by Herrys and Whittington. ${ }^{59}$

\subsection{The poor, the young and prisoners}

Philanthropists also showed concern for vulnerable members of society by supporting the poor, the young and prisoners. Thomas Knolles, for example, left money to the poor of his parish and his guild as well as " $4 \mathrm{~d}$ to each person incarcerated in the prisons of Newgate, Ludgate, Fleet, Marshalsea, and King's Bench, to pray for my soul” and provided some social rehabilitation for imprisoned debtors by discharging their debts. ${ }^{60}$ Whether such bequests provided short-term or long-term alleviation is difficult to judge. John Herrys bequeathed 
money for Irish cloth to be made into garments for the poor at his funeral, which they were allowed to keep. Dowries provided to "poor maidens," also funded by entrepreneurs, provided financial security and may have been intended to encourage marriage and prevent prostitution.

\subsection{Employees}

Support for employees focused on the provision of cash. Vintner and wool trader Richard Russell, for example, left $£ 30$ to be distributed amongst the sheep-farmers of the Yorkshire Wolds and Lindsey in Lincolnshire from whom he had purchased wool. ${ }^{61}$ The Suffolk clothier Thomas Spring II meanwhile, bequeathed 100 marks (£67) to be distributed to his "spinners, weavers, and fullers." 62 As businesses were smaller in the middle ages, and apprentices resided with their masters, there was probably little demand for the housing and recreational facilities of the kind that industrialist philanthropists later provided for their employees.

\section{Comparison with other occupations}

Comparison with members of other occupations can inform on the extent to which the features noted above are specific to entrepreneurs. Lawyers, gentry, and administrators were chosen as comparisons, as described above (Table 3). ${ }^{63}$ The comparison reveals that entrepreneurs had a greater tendency towards philanthropy than the other occupations. Thirtynine percent of entrepreneurs were philanthropic, compared to 23 per cent of administrators, 22 per cent of gentry and 19 per cent of lawyers.

Differences occurred between the causes supported by entrepreneurs and those supported by other professions. Entrepreneurs supported a wider range of causes and showed particularly strong support for municipal improvements, which formed 22 per cent of their total recorded donations, compared to only 2 per cent of those of administrators and none of lawyers and the gentry. John Cobham is a rare example of an administrator who supervised and funded municipal improvements in and around his home county of Kent, including the reconstruction of Rochester Bridge in 1383 and the restoration of Canterbury's walls in $1385 .^{64}$

Education was supported to a greater extent by administrators than entrepreneurs, and also received some support from the gentry. Three administrators, Adam Brome, Hervey Stanton, and Robert Wodelarke, founded the university colleges of Oriel, Oxford, Michaelhouse, Cambridge (which was later absorbed into Trinity), and St Catharine's, 
Cambridge respectively, while William Windsor gave a substantial endowment to New College, Oxford. ${ }^{65}$ Joan Greyndour used wealth inherited from her parents and her first husband, an administrator, to establish a grammar school in his memory in the Forest of Dean in 1445-1446. ${ }^{66}$ The commemorative aspect was reflected in the provision of a chantry on the site. Administrator Thomas Kent and the gentry Cobham family, meanwhile, donated books to Oxford University. ${ }^{67}$

Religion received the highest proportion of donations from lawyers, gentry, and administrators. House and church foundation was more pronounced amongst those groups than amongst entrepreneurs, with three philanthropic administrators and three philanthropic gentry' families undertaking such projects. Administrator Nicholas Cantilupe, having disinherited his son and heir, founded two religious institutions during his lifetime, Beauvale Priory near Nottingham and Cantilupe College in Lincoln Cathedral close. ${ }^{68}$ The use of religious patronage to enhance political and social authority has been noted by historians as a feature of these social groups, and this may be reflected in our findings. ${ }^{69}$ Donations by Somerset administrator Walter Hungerford (1378-1449), for example, corresponded closely with Henry V's support for the Carthusians and Dominicans. ${ }^{70}$ Michael de la Pole, son of the famous entrepreneur William de la Pole, sought a career in administration rather than trade but acted in accordance with his father's wishes to establish a religious house in Hull to commemorate the family. ${ }^{71}$

Comparison of philanthropy before and after death also reveals differences between the groups. Administrators and gentry families made a greater volume of bequests during their life (54 per cent and 71 per cent respectively) compared to entrepreneurs ( 28 per cent), and lawyers (43 per cent). This difference may have arisen because entrepreneurs retained capital during their life to reinvest in their business, a characteristic noted of Richard Whittington.

\section{Comparison between philanthropy and alternative sources of wealth}

Entrepreneurs had a range of options available to them to dispose of their wealth, of which philanthropy was only one (Table 2). Sixty-one percent of entrepreneurs recorded in the $O D N B$ were not philanthropic, either from choice or necessity. Great Yarmouth merchant John Perbroun, for example, had all his capital invested in his business and paid large amounts of tax..$^{72}$

Table 6 shows that residential improvements and lending at interest were popular alternative uses of wealth for non-philanthropic entrepreneurs. Business gambles were also 
popular, and biographies reveal that several entrepreneurs participated in the failed customs schemes organized to finance the Hundred Years War, which may have left little spare money for philanthropy. ${ }^{73}$ Family bequests were relatively unpopular and use of wealth for pleasure appears to have been non-existent. Indications are that non-philanthropic entrepreneurs preferred to spend their money in ways that resulted in additional profit (such as interest payments, rental income, and trading privileges). They therefore displayed qualities of acquisitiveness later imputed to early modern entrepreneurs. ${ }^{74}$

Philanthropists also put their wealth to additional uses. Residential improvements were the most popular alternative option for philanthropic entrepreneurs. Roger Thornton, for example invested his money from the wool, cloth and lead trades in at least six properties in London, one of which doubled as a business base in the city, while Chestre built a house on Bristol's High Street in $1472 .{ }^{75}$ Philanthropic entrepreneurs were more generous in their support of family members and took fewer business gambles, with the exception of Pyel's involvement in a customs syndicate and Canynges's financing of the unsuccessful 1457 Aegean Sea expedition. ${ }^{76}$

Philanthropic lawyers, administrators, and gentry favored bequests to family, residential improvements and acquiring political influence. Pleasure was not off the agenda for those groups however. Philanthropic lawyer John Heydon invested in residential improvements, supported his family and sought political influence but also reportedly kept a mistress. ${ }^{77}$

\section{Reputation and legacy}

Philanthropy provided benefits for donors as well as recipients. Many were commemorated publically, although whether this was their intention from the outset is unclear. Blackburn and Thornton symbolically linked their philanthropy to the Corporal Acts of Mercy and are commemorated in stained glass windows at All Saints Church, York (surviving) and in All Saints church, Newcastle (lost) ${ }^{78}$ Others became role models for subsequent generations. Whittington's legend began soon after his death in the 1436 poem The Libel of English Policy, where he was described as "having worthiness that pen and paper may not...describe," and was the subject of a widely disseminated play of $1605 .{ }^{79}$ The legacy of Canynges philanthropy continued into the nineteenth century and beyond when he was promoted as an ecclesiastical 
patron by the parishioners of St Mary Redcliffe church, Bristol, during their 1842-1872 restoration appeal and subsequent appeals from 1927 to the present. ${ }^{80}$

Later commentators sometimes magnified philanthropic gestures by emphasizing, in the absence of detailed evidence, the humble origins of the donors. Sevenoak featured in the poem The Nine Worthies of London (1584), which stated his achievements after a humble birth like "a weed, that grew full low." ${ }^{81}$ Depicted as a peddler in the play The Love Sick King (1655), Thornton's character states that if he makes a fortune he will "comfort the poor, and perhaps build churches." 82 There are hints from commemoration that personal experience of hardship influenced the reinvestment of the rewards of success in philanthropic endeavours.

\section{Conclusion and implications for future research}

Medieval entrepreneurs perceived a harmony between self-interest and social interest, our study suggests. They not only supported causes directly connected with religion, but also others, such as municipal infrastructure and education, which enhanced entrepreneurial opportunities more generally. There are indications that philanthropic entrepreneurs identified causes through a combination of experience accumulated during their career, knowledge derived from religious teachings, which emphasized support for the vulnerable, and from periods in civic office, which highlighted gaps in government provision. ${ }^{83}$

Entrepreneurs exhibited distinctive patterns of philanthropy compared to other groups. They were more likely to engage in philanthropy compared to lawyers, administrators, and gentry families, and supported a wider range of causes. There are indications that they applied their business skills to identify and fill gaps in existing provision, rather than operating solely through the existing framework of religious institutions and guilds. ${ }^{84}$ Support for municipal infrastructure emerges as a distinctive feature of entrepreneurial philanthropy, reflecting their belief in the importance of trade networks and civic reputation. Reinvestment of wealth by entrepreneurs supplemented the resources of local government and almost certainly improved the overall competitive performance of the recipient town.

Personal and family circumstances influenced philanthropy. Support from a wealthy wife was valuable. Absence of descendants or unsuitable heirs encouraged investment in the wider community. Relocation from a provincial birthplace in search of better opportunities was fairly common, but many successful 'movers' continued to support their birthplace. 
Entrepreneurs had other opportunities to dispose of their wealth, including through residential improvements, business gambles and family bequests. Yet, despite that, many chose to use the profits of trade to support both current residents and future generations of their wider community. Entrepreneurs made significant philanthropic contributions to the provision of infrastructure, healthcare and education. Future research would benefit from supplementing the qualitative analysis with quantitative analysis, particularly by engaging with the unresolved debates surrounding Jordan's calculations of monetary values of donations. ${ }^{85}$

CATHERINE CASSON is a Lecturer in Enterprise at Alliance Manchester Business School, University of Manchester. Casson's publications include a co-authored book with Mark Casson on The Entrepreneur in History: From Medieval Merchant to Modern Business Leader (Palgrave Macmillan, 2013) and articles in Urban History, Business History and the Economic History Review. She is currently the co-editor, together with Georg Christ, of Bloomsbury's A Cultural History of Business in the Medieval Age (800 - 1450), and contributor to The Routledge Companion to Makers of Global Business.

MARK CASSON is Professor of Economics and Director of the Centre for Research in Institutions and Economic History at the University of Reading. He has published in Economic History Review, Explorations in Economic History, Business History Review, Business History, Economic Journal and other leading journals. He is the co-author (with Catherine Casson) of The Entrepreneur in History and co-editor (with Nigar Hashimzade) of Large Databases in Economic History (Routledge, 2013). 
Acknowledgements: We would like to acknowledge feedback from the editors of the special issue, the other contributors and the referees. Thanks also go to Craig Lambert.

$1 \quad$ Mark Casson and Catherine Casson, The Entrepreneur in History: From Medieval Merchant to Modern Business Leader (Basingstoke, 2013).

2 For extended gentry families the number of members results in less precision on death dates, and so we include some where the dynasty was finishing in or just after 1500.

3 Previous work on philanthropy has often been based on wills and testaments, as described below, and assigned monetary values to the donations. These sources do not survive for many of the individuals in our study, and so information on their activities is derived from a wider range of records in which monetary values are rarely reported.

4 Mairi Maclean, Charles Harvey and S. Clegg, "Organization Theory in Business and Management History: Present Status and Future prospects," Business History Review, 91 (2017): 457-481; R. D. Wadhawani and G Jones, "Schumpeter's Plea: Historical Reasoning in Entrepreneurship Theory and Research" in Organizations in Time: History, Theory, Methods eds. M. Bucheli and R.D. Wadhwani (Oxford, 2014): 192-216; Kleio Akrivou and Alejo José G. Sison eds., The Challenges of Capitalism for Virtue Ethics and the Common Good Interdisciplinary Perspectives (Cheltenham, 2016).

5 W. K. Jordan, Philanthropy in England 1480-1660: A Study of the Changing Pattern of English Social Aspirations (London, 1959): 360-1.

6 Clive Burgess, “'By Quick and by Dead': Wills and Pious Provision in Late Medieval Bristol,” The English Historical Review, 102 (405) (1987): 837-58.

7 Joel T. Rosenthal, The Purchase of Paradise: Gift Giving and the Aristocracy, 1307-1485 (London and Toronoto, 1972); Jordan, Philanthropy.

8 Jordan, Philanthropy.

9 Charles Harvey, Mairi Maclean, Jillian Gordon and Eleanor Shaw, "Andrew Carnegie and the Foundations of Contemporary Entrepreneurial Philanthropy," Business History 53:3 (2011): 425-50; David J. Jeremy, "The Enlightened Paternalist in Action: William Hesketh Lever at Port Sunlight before 1914," Business History 33 (1) (1991): 58-81; David J. Jeremy, Capitalists and Christians: Business Leaders and the Churches in Britain 19001960 (Oxford, 1990).

10 Mairi Maclean, Charles Harvey, Jillian Gordon and Eleanor Shaw, "Identity, Storytelling and the Philanthropic Journey," Human Relations 68: 10 (2015): 1623-52; Frank Prochaska, Schools of Citizenship: Charity and Civic Virtue (London, 2002): 47.

11 R. Bekkers and P. Wiepking, "A Literature Review of Empirical Studies of Philanthropy: Eight Mechanisms that Drive Charitable Giving," Nonprofit and Voluntary Sector Quarterly 40 (2011): 924-73.

12 Maclean et al., "Identity."

13 Jeremy, Capitalists.

14 People in $O D N B$ who are entrepreneurs according to our definition but who are not philanthropic are: Thomas Romeyn (d. 1313), William Servat (d. 1318/9), Richer Refham (d. 1328), Richard Embleton (d. c. 1333), John Crab (d. c. 1352), Henry Picard (d. 1361), Thomas Melchebourne (d. 1356), William Melchebourne (d. c. 1360), John Wesenham (d. 1382), John Goldbeter (d. 1364), John Perbroun (d. 1342/3), Walter Chiriton (d. c. 1358), Adam Fraunceys (d. 1375), Simon Fraunceys (d. 1358), Andrew Aubrey (d. 1356), Nicholas Brembre (d. 1388), Bartholomew Bosan (d. 1400), Hugh Fastolf (d. 1392), William de la Pole (d. 1366), Robert Wilford (d. 1396), Gilbert Maghfeld (d. 1397), John Pecche (d. 1380), Richard Lyons (d. 1381), Mark LeFayre (d. 1417/18), Robert Sturmy (d. 1458), Gabriel Corbet (d. 1454), William Cantelowe (d. 1464), Ralph Holland (d. 1452), John Halle (d. 1479), James Falleron (d. c. 1463), John Browne (d. 1476), Margaret Burton (d. 1488), Isabel Nunhouse (d. c. 1442), Nichola Irby (d. 1395), Katherine Lam (d. 1484), Katherine Lakensnyder (d. 1394), Alice Folston (d. c. 1395), Cecily Yharom (d. 1396), Marion Kent (d. 1500), Agnes Ramsey (d. c. 1399), Joan Hill (d. 1441), Hamo Chigwell (d. 1332), and John Causton (d. 1353).

15 John Benjamin Heath, Some Account of the Worshipful Company of Grocers of the City of London (London, 1854); Charles Henry Cooper (1842) Annals of Cambridge, Volume I (Cambridge, 1842).

16 Sandra Raban, "Mortmain in Medieval England," Past and Present, 62 (1974): 3-26.

17 Gervase Rosser, The Art of Solidarity in the Middle Ages: Guilds in England 1250-1550 (Oxford, 2015).

18 Rosenthal, Paradise: 9-10.

19 R. N. Swanson, Religion and Devotion in Europe, c. 1215-c. 1515 (Cambridge, 1995): 206-25.

20 James Davis, Medieval Market Morality: Life, Law and Ethics in the English Marketplace, $1200-1500$ (Cambridge, 2012).

21 M. Rubin, Charity and Community in Medieval Cambridge (Cambridge, 1987): 1. 
22 M. R. Macdonald, “Clopton, Hugh (c.1440-1496)," ODNB; R. R. Sharpe ed., Calendar of Wills Proved and Enrolled in the Court of Husting, London: Part 2, 1358-1688 (London, 1890): 595.

23 Stephen Alsford, "Pious and Charitable Bequests," Medieval English Towns, accessed 6 October 2017 http://users.trytel.com/tristan/towns/florilegium/lifecycle/lcdth19.html.

24 Stephen Alsford, "The Wills and Testaments of Three London Grocers," Medieval English Towns, accessed 6 October 2017, http://users.trytel.com/tristan/towns/florilegium/lifecycle/lcdth12.html.

25 V. Henn, "Lemberg, Tideman (c.1310-1386)," ODNB.

26 Paul Strohm, "Twyford, Sir Nicholas (d. 1390/91)," ODNB; Lorna E. M. Walker, "Barantyn, Drew (c.13501415)," ODNB; History of Parliament; The National Archives TNA PROB 11/2B/82; T. F. Reddaway and Lorna Walker, The Early History of the Goldsmiths Company (London, 1975): 279-82.

27 History of Parliament.

28 Sutton, "Whittington," ODNB; History of Parliament; Burgess, "Canynges," ODNB.

29 Alsford, "Pious"; History of Parliament.

30 History of Parliament; Alsford, "Wills"; Heath, Grocers: 221-3.

31 Caroline M. Barron, "Eyre, Simon (c.1395-1458)," ODNB.

32 History of Parliament; Alsford, "Wills"; Heath, Grocers: 221-3.

33 Heath, Grocers: 223-4; Richard Arnold, The Customs of London, Otherwise called Arnold's Chronicle (London, 1811): xxxiii; H. C. Maxwell Lyte, Calendar of Patent Rolls Preserved in the Public Record Office Henry VI Vol. III 1436-41 (London, 1907): 142, 232, 253, 345; Buchanan Sharp, Famine and Scarcity in Late Medieval and Early Modern England: The Regulation of Grain Marketing, 1256-1631 (Cambridge, 2016$): 142$.

34 Caroline M. Barron, "Forster, Agnes (d. 1484),"ODNB; Reginald R. Sharpe ed. Calendar of Letter-Books of the City of London: L, Edward IV-Henry VII (London, 1912): 40.

35 Caroline M. Barron, "Eyre, Simon (c.1395-1458)," ODNB.

36 David Harrison, The Bridges of Medieval England: Transport and Society 400-1800 (Oxford, 2004).

37 George Holmes, "Eastfield, Sir William (d. 1446)," ODNB.

38 Nicholas Martin Herbert, "The Borough of Wallingford 1155-1400" (PhD diss., University of Reading, 1970): 150 .

39 Stephen Alsford, “Testaments of a Devout Husband and Wife," Medieval English Towns, accessed 6 October 2017 http://users.trytel.com/tristan/towns/florilegium/lifecycle/lcdth16.html; Clive Burgess, "Chestre, Alice (d. 1485)," ODNB; Peter Fleming, "Women in Bristol, 1373-1660" in Women and the City: Bristol, 13732000 ed. M. Dresser (Bristol, 2016): 15-44, 27; Burgess, “"Quick.”

40 Carole Rawcliffe, Urban Bodies: Communal Health in Late Medieval English Towns and Cities (Woodbridge, 2013).

41 John S. Lee, "Piped Water Supplies Managed By Civic Bodies in Medieval English Towns," Urban History (2014): 1-25.

42 Lee, "Water".

43 Oliver Creighton and Robert Higham, Medieval Town Walls: An Archaeology and Social History of Urban Defence (Stroud, 2005).

44 Stephen Alsford, "Wills of Two Southampton Mayors," Medieval English Towns, accessed 6 October 2017, http://users.trytel.com/tristan/towns/florilegium/lifecycle/lcdth15.html; A.B. Wallis Chapman, ed., The Black Book of Southampton, Volume II (Southampton, 1912); History of Parliament; Tom Beaumont James, "Soper, William (d. 1459)," ODNB; Helen Bradley, "Southampton's Trading Partners: London" in English Inland Trade 1430-1540: Southampton and its Region, ed. Michael Hicks (Oxford, 2015):65-80; Colin Platt, Medieval Southampton: The Port and Trading Community, A.D. 100-1600 (London and Boston, 1973): 257-8.

45 Pamela Nightingale, "Walworth, Sir William (d. 1386?)," ODNB.

46 L. F. Salzman ed. A History of the County of Cambridge and the Isle of Ely: Volume 2 (London, 1948): 21017; R. R. Sharpe ed., Calendar of Wills Proved and Enrolled in the Court of Husting, London: Part 1, 1258-1358 (London, 1889): 649-51.

47 E. MacKenzie, A Descriptive and Illustrative Account of the Town and County of Newcastle including the Vicinity of Gateshead Vol 1 (1827, Newcastle): 119; James Raine ed., Wills and Inventories Illustrative of the History, Manners, Language, Statistics Etc of the Northern Counties of England from the Eleventh Century: Part 1 (1884-5, London): 164-7. History of Parliament; Christian D. Liddy, The Bishopric of Durham in the Late Middle Ages: Lordship, Community and the Cult of St Cuthbert (Woodbridge, 2008): 56.

48 Alsford, "Wills"; Heath, Grocers: 208-11; History of Parliament.

49 R. M. Serjeantson and W. R. D. Adkins eds., A History of the County of Northampton: Volume 2 (London, 1906): 179-180. Stephen O'Connor, "Pyel, John (c.1315-1382)," ODNB; S. J. O'Connor, ed., A Calendar of the Cartularies of John Pyel and Adam Fraunceys (London, 1993); S. J. O'Connor, "Finance, Diplomacy and Politics: Royal Service by Two London Merchants in the Reign of Edward III," Historical Research, 67 (1994): 18-39; S. J. O'Connor, "Adam Fraunceys and John Pyel: Perceptions of Status Among Merchants in Fourteenth-Century London" in Trade, Devotion and Governance: Papers in Later Medieval History ed. D. J. Clayton, R. G. Davies 
and Peter McNiven (Stroud, 1994); S. J. O'Connor, "Joan Pyel” in Medieval London Widows, 1300-1500, ed. C. M. Barron and A. F. Sutton (London: 1994): 71-76.

50 Kenneth E. Munn, Hidden Portraits of Henry VII's Family and Court Depicted in the Stained Glass at St Mary's Church Fairford (NS, 2016); N. M. Herbert ed. A History of the County of Gloucester: Volume 7 (Oxford, 1981): 69-86; John Mason Neale ed., Illustrations of Monumental Brasses, No.VI (Cambridge, 1846):115-132; R. R. Sharpe ed., Calendar of Wills Proved and Enrolled in the Court of Husting, London: Part 2, 1358-1688, (London, 1890): 117-18; Charles Welch, “Lovekyn, John (d. 1368),' rev. Roger L. Axworthy,” ODNB; W. Herbert, The History and Antiquities of the Parish and Church of St. Michael, Crooked Lane, London (London, 1831): $122-60$.

51 Patricia H. Cullan, “' 'For Pore People Harberles': What Was the Function of the Maisonsdieu?', in Trade, Devotion and Governance: Papers in Later Medieval History, ed. Dorothy J. Clayton, Richard G. Davies and Peter McNiven (Stroud 1994): 36-52; Stephen Alsford, "Whittington's Charity," Medieval English Towns, accessed 6 October 2017, http://users.trytel.com/tristan/towns/florilegium/community/cmreli17.html.

52 Cooper, Annals: 105-6; Rubin, Charity: 120-23; Salzman, ed., Cambridge: 307

53 J. C. Hodgson, "The "Domus Dei of Newcastle Otherwise St Katherine's Hospital on the Sandhill," Archaeologia Aeliana $3^{\text {rd }}$ series Vol. XIV: 191-220.

54 Alsford, "Wills."

55 Heath, Grocers: 213-21; History of Parliament; Pamela Nightingale, "Sevenoak, William (d. in or after 1432)," ODNB.

56 Caroline M. Barron, "Eyre, Simon (c.1395-1458)," ODNB.

57 Cooper, Annals: 105-6; Mayors and Bailiffs of Cambridge to 1380 Cole MS Addit. 5833: 126-35, F. W. Maitland, Township and Borough (Cambridge, 1898):134-41; Rubin, Charity: 120-23.

58 Cooper, Annals: 216; Rubin, Charity: 280.

59 History of Parliament; Anne F. Sutton, "Whittington, Richard (c.1350-1423)," ODNB;

Cooper, Annals: 170; Rubin, Charity: 124, 191, 262-63; W. M. Palmer, ed., Cambridge Borough Documents (Cambridge, 1931): 152.

60 Alsford, "Wills"; Heath, Grocers: 205-8; History of Parliament; Pamela Nightingale, "Knolles, Thomas (d. 1435),"ODNB.

61 Alsford, "Pious."

62 Phillipp R. Schofield, "Spring Family (per. c.1400-c.1550)," ODNB.

63 Philanthropic lawyers are John Heydon (d. 1479) William Yelverton (d. c. 1477), Richard Newton (d. 1448), William Hankeford (d. 1423), Richard Bank (d. 1415), William [i] of the Stourton family (d. 1413), Henry Green (d. 1369), John Stonor (d. 1351), Geoffrey Scrope (d. 1340), the Catesby family (finished c. 1500). Philanthropic administrators are Richard Ravenser (d. 1386), William of Carleton (d. c. 1311), John Benstede (d. 1323), John Thorpe (d. 1324), Robert Clitheroe (d. 1334), Hugh Despenser the younger (d. 1326), Hervey Stanton (d. 1327), Adam Brome (d. 1332), Henry Cliffe (d. 1334), Geoffrey Scrope (d. 1340), Thomas Baumburgh (d. 1340), Roger Wodehouse (d. 1346), Nicholas Cantilupe (d. 1355), Robert of Sadyngton (d. c. 1361) Ralph Neville (d. 1367), Ralph Stafford (d. 1372), Stourton family (f. c. 1485), William Windsor (d. 1384), Neil Loring (d. c. 1386), Michael de la Pole (d. c. 1389), John Newenham (d. 1390), Richard Scrope (d. c. 1403), John Cobham (d. 1408), John Rochford (d. c. 1410), Henry Scrope (d. c. 1415), Thomas Camoys (d. 1420/1), John Pelham (d. 1429), Richard Buckland (d. 1436), Thomas Lisieux (d. 1456), Walter Hungerford (d. 1449), Ralph Cromwell (d. 1456), Thomas Kent (d. 1469), John Tiptoft (d. 1470), John Wenlock (d. 1471), Ralph Boteler (d. 1473), Robert Wodelarke (d. c. 1481), Joan Greyndour (d. c. 1485), Thomas Burgh (d. c. 1496). Philanthropic gentry families are Kyme (f. c, 1380), d'Abenon (f. 1400), de Dive (f. 1310), Bek (f. c. 1350), Chaworth (f. c. 1521), Dinham (f; c. 1500), Cobham (f. c. 1530), Abberbury (f. c. 1475), Catesby (f. 1505), Stourton (f. c. 1485), Culpeper (f. c. 1540).

64 Rosamund Allen, "Cobham, John, third Baron Cobham of Cobham (c.1320-1408)," ODNB.

65 Jeremy Catto, "Brome, Adam (d. 1332)," ODNB; Paul Brand, "Stanton, Hervey (c.1260-1327)," ODNB; J. H. Baker, "Wodelarke, Robert (d. 1481?)," ODNB; Philomena Connolly, "Windsor, William, Baron Windsor (1322x8-1384)," ODNB.

66 Nicholas Orme, "Greyndour, Joan (c.1400-1485)," ODNB.

67 Roger Virgoe, "Kent, Thomas ( $b$. in or before 1410, d. 1469)," ODNB; Linda Clark, Peter Fleming, "Cobham family (per. c.1250-c.1530)," ODNB.

68 Richard Partington, "Cantilupe , Nicholas, third Lord Cantilupe (c.1301-1355)," ODNB; William Page ed., A History of the County of Nottingham: Volume 2 (London, 1910): 105-109.

69 Elizabeth Gemmill, The Nobility and Ecclesiastical Patronage in Thirteenth-Century England (Woodbridge, 2013); Sarah Rees Jones, York: The Making of a City, 1068-1350 (Oxford, 2013).

70 Charles Kightly, "Hungerford, Walter, first Baron Hungerford (1378-1449)," ODNB. 
71 Rosemary Horrox, The De La Pole Family of Hull (Beverley, 1983); K J Allison ed., A History of the County of York East Riding: Vol.1, The City of Kingston Upon Hull (London, 1969): 11-85; Anthony Tuck, "Pole, Michael de la, first earl of Suffolk (c.1330-1389)," ODNB.

72 A. Saul, "Perbroun, John (d. 1342/3)," ODNB.

73 E. B. Fryde, "The English Farmers of the Customs, 1343-51," Transactions of the Royal Historical Society Volume 9 (December 1959): 1-17; George Sayles, “"The 'English Company' of 1343 and a Merchant's Oath," Speculum 6 (2) (1931): 177-205.

74 Richard H. Tawney, Religion and the Rise of Capitalism (London, 1936).

75 Hodgson, "Domus Dei": 191-220; History of Parliament; MacKenzie, Newcastle; Burgess, "Chestre, Alice (d. 1485)," ODNB.

76 Stephen O'Connor, "Pyel, John (c.1315-1382),"ODNB; "William Canynges, ” accessed 1 July 2017, http://www.stmaryredcliffe.co.uk/william-canynges.html.

77 Anthony Smith, "Heydon, John (d. 1479),"ODNB.

78 MacKenzie, Newcastle: 242; All Saints Stained Glass, accessed 1 October 2017, http://allsaintsnorthstreet.org.uk/stainedglass.html.

79 G. A. Holmes, "The 'Libel of English Policy'," The English Historical Review 76 (299) (1961): 193-216; Anne F. Sutton, "Whittington, Richard (c.1350-1423)," ODNB; Thomas Wright (ed.), Political Poems and Songs Relating to English History Composed During the Period from the Accession of Edward III to that of Richard II Vol. 2 (London, Longman, Green, Longman and Robert, 1861): 178; C. M. Barron, "Richard Whittington: The Man Behind the Myth," Studies in London History Presented to Philip Edmund Jones, ed. A. E. J. Hollaender and W. Kellaway (1969): 197-248; Alan J. Drosdick, "In Danger of Undoing: The Literary Imagination of Apprentices in Early Modern London" (PhD thesis, University of California, Berkeley, 2010).

${ }_{80}$ Linda Monckton, "The Myth of William Canynges and the Late Medieval Rebuilding of St Mary Redcliffe" in "Almost the Richest City:" Bristol in the Middle Ages ed. Laurence Keen (Leeds, 1997): 57-67; "Restoration Appeal of 1842," accessed 1 July 2017, http://www.stmaryredcliffe.co.uk/restoration-appeal-1842.html; "The Canynges Society," accessed 1 July 2017, http://www.stmaryredcliffe.co.uk/the-canynges-society.html.

81 Richard Johnson, The Nine Worthies of London (1584).

82 Anthony Brewer, The Love-Sick King, An English Tragical History with the Life and Death of Cartesmunda, the Fair Nun of Winchester (1655).

83 Jeremy, Capitalists.

84 Prochaska, Citizenship: 47

85 These debates are summarized in L. Stone, "Review of Philanthropy in England, 1480-1660: A Study of the Changing Pattern of English Social Aspirations by W. K. Jordan, London: Allen and Unwin. 1959.410 pp. 42s.," History: The Journal of the Historical Association 44 (1959): 257-60; Lawrence Stone, "Review of

The Charities of London, 1480-1660 by W. K. Jordan," The English Historical Review, 77: 303 (April 1962): 327-9; D. C. Coleman, "Review of Philanthropy in England 1480-1660. A Study of the Changing Pattern of English Social Aspirations by W. K. Jordan," Economic History Review, 13: 1 (1960): 113-5; Alan Everitt, "Social Institutions in Kent, 1480-1660: A Study of the Changing Pattern of Social Aspirations, by W. K. Jordan," Economic History Review 15:2 (1962): 376-7. For later critical assessment, see William. G. Bitte and R. Todd Lane, "Inflation and Philanthropy in England: A Re-Assessment of W. K. Jordan's Data," Economic History Review 29: 2 (1976): 203-10 and D. C. Coleman, "Philanthropy Deflated: A Comment," Economic History Review 31: 1 (1978): 119. For a partial defense of Jordan, see J. F. Hadwin, "Deflating Philanthropy," Economic History Review 31: 1 (1978): 105-17, and C. Wilson, 'Poverty and Philanthropy in Early Modern England', in Aspects of Poverty in Early Modern Europe ed. Thomas Riis (Alphen aan den Rijn, 1981): 253-79. 
Appendix 1

Sample of 44 entrepreneurs

\begin{tabular}{|c|c|c|c|c|c|}
\hline $\begin{array}{l}\text { Name, dates of birth and } \\
\text { death }\end{array}$ & Location & Occupation & $\begin{array}{l}\text { Office } \\
\text { holder }\end{array}$ & $\begin{array}{l}\text { Surviving } \\
\text { children }\end{array}$ & Sources \\
\hline $\begin{array}{l}\text { Richard Andrew } \\
\text { d. c. } 1459\end{array}$ & Cambridge & Spicer & $\mathrm{Y}$ & & Cooper; $H P$; Rubin. \\
\hline $\begin{array}{l}\text { Drew Barantyn } \\
\text { c. } 1350-1415\end{array}$ & $\begin{array}{l}\text { 1.Chalgrove, } \\
\text { Oxon } \\
\text { 2.London }\end{array}$ & $\begin{array}{l}\text { Goldsmith and } \\
\text { financier }\end{array}$ & $\mathrm{N}$ & $\mathrm{N}$ & $\begin{array}{ll}O O D N B ; & H P \\
\text { Reddaway } & \text { and } \\
\text { Walker; TNA. } & \end{array}$ \\
\hline $\begin{array}{l}\text { Nicholas Blackburn } \\
\text { d. c. } 1432\end{array}$ & $\begin{array}{l}\text { 1.Richmond, } \\
\text { Yorkshire } \\
\text { 2.York } \\
\end{array}$ & Merchant & $\mathrm{Y}$ & $\mathrm{Y}$ & Alsford, "Testaments" \\
\hline $\begin{array}{l}\text { Stephen Brown } \\
\text { Early } 14^{\text {th }} \text { century }\end{array}$ & London & Grocer & $\mathrm{Y}$ & & Heath: 223-4. \\
\hline $\begin{array}{l}\text { William Browne } \\
\text { d. } 1489\end{array}$ & $\begin{array}{l}\text { Stamford, } \\
\text { Lincolnshire }\end{array}$ & Draper & $\bar{Y}$ & $\mathrm{Y}$ & $O D N B$ \\
\hline $\begin{array}{l}\text { Richard Buckland } \\
\text { d. } 1436\end{array}$ & $\begin{array}{l}\text { 1.Devon } \\
\text { 2.London }\end{array}$ & $\begin{array}{l}\text { Fishmonger and ship } \\
\text { owner }\end{array}$ & $\mathrm{N}$ & $\mathrm{Y}$ & Furnivall: $104-8$ \\
\hline $\begin{array}{l}\text { Roesia Burford } \\
\text { d. } 1329\end{array}$ & $\begin{array}{ll}\text { London } & \text { and } \\
\text { possibly } & \text { also } \\
\text { Oxford } & \\
\end{array}$ & $\begin{array}{lr}\text { Daughter } & \text { of } \\
\text { merchant, pepperer } \\
\text { and former mayor and } \\
\text { wife of a wool } \\
\text { exporter }\end{array}$ & $\mathrm{N}$ & $\mathrm{Y}$ & $O D N B$ \\
\hline $\begin{array}{l}\text { William Canynges } \\
1402-1474\end{array}$ & Bristol & $\begin{array}{l}\text { 1. Cloth trader; } 2 . \\
\text { Ship-owner; } \\
\text { 3. Priest }\end{array}$ & $\mathrm{Y}$ & $\mathrm{N}$ & $O D N B$ \\
\hline $\begin{array}{l}\text { Alice Chestre } \\
\text { d. } 1485\end{array}$ & Bristol & $\begin{array}{l}\text { Widow of Henry } \\
\text { Chestre (draper) and } \\
\text { business woman }\end{array}$ & $\mathrm{N}$ & $\mathrm{Y}$ & $O D N B$ \\
\hline $\begin{array}{l}\text { Robert Chichele } \\
\text { d. } 1438\end{array}$ & $\begin{array}{l}\text { 1.Northamp- } \\
\text { tonshire } \\
\text { 2.London }\end{array}$ & Grocer & $\mathrm{Y}$ & $\mathrm{N}$ & $\begin{array}{l}\text { HP; Heath: 208-11; } \\
\text { Alsford, "Wills". }\end{array}$ \\
\hline $\begin{array}{l}\text { Hugh Clopton } \\
\text { c. } 1440-1496\end{array}$ & $\begin{array}{l}\text { 1.Stratford- } \\
\text { upon-Avon } \\
\text { 2.London } \\
\end{array}$ & Merchant & $\mathrm{Y}$ & $\mathrm{N}$ & $O D N B$ \\
\hline $\begin{array}{l}\text { John Crosby } \\
\text { d. } 1479\end{array}$ & London & $\begin{array}{l}\text { Grocer and wool } \\
\text { exporter }\end{array}$ & $\mathrm{Y}$ & $\mathrm{Y}$ & $\begin{array}{l}O D N B \text {; Heath: 229- } \\
34 .\end{array}$ \\
\hline $\begin{array}{l}\text { William Eastfield } \\
\text { d. } 1446\end{array}$ & $\begin{array}{l}\text { 1.Tickhill, } \\
\text { Yorkshire } \\
\text { 2.London }\end{array}$ & Mercer & $\bar{Y}$ & $\mathrm{Y}$ & $O D N B$ \\
\hline $\begin{array}{l}\text { Simon Eyre } \\
\text { c. } 1395-1458\end{array}$ & $\begin{array}{l}\text { 1.Brandon, } \\
\text { Suffolk } \\
\text { 2.London } \\
\end{array}$ & Cloth middleman & $\mathrm{Y}$ & $\mathrm{Y}$ & $O D N B$ \\
\hline $\begin{array}{l}\text { Agnes Forster } \\
\text { d. } 1484\end{array}$ & \begin{tabular}{|l|} 
1.Kent \\
2.London
\end{tabular} & $\begin{array}{l}\text { Widow of ship owner } \\
\text { and merchant }\end{array}$ & $\mathrm{N}$ & $\mathrm{Y}$ & $O D N B$ \\
\hline $\begin{array}{l}\text { Richard Gage } \\
\text { d. } 1444\end{array}$ & Salisbury & Draper & $\mathrm{Y}$ & & $\begin{array}{l}\text { Crittall: } 124-29 ; 132- \\
36 .\end{array}$ \\
\hline $\begin{array}{l}\text { Richard Garner } \\
\text { d. in or after } 1415\end{array}$ & $\begin{array}{l}\text { 1.Piedmont, } \\
\text { Italy } \\
\text { 2.London }\end{array}$ & Vintner & $\mathrm{N}$ & & $O D N B$ \\
\hline $\begin{array}{l}\text { John Hawley the elder } \\
\text { c. } 1350-1408\end{array}$ & Dartmouth & Merchant and pirate & $\mathrm{Y}$ & $\mathrm{Y}$ & $O D N B ; H P$ \\
\hline
\end{tabular}




\begin{tabular}{|c|c|c|c|c|c|}
\hline $\begin{array}{l}\text { John Herrys } \\
\text { d. } 1423\end{array}$ & Cambridge & Merchant & $\mathrm{Y}$ & & Palmer; Rubin. \\
\hline $\begin{array}{l}\text { Thomas Knolles } \\
\text { d. } 1435\end{array}$ & London & Grocer & $\mathrm{Y}$ & $\mathrm{Y}$ & $\begin{array}{l}O D N B ; H P ; \text { Heath, } \\
\text { Alsford, "Wills" }\end{array}$ \\
\hline $\begin{array}{l}\text { Tidemann Lemberg } \\
\text { 1310-1386 }\end{array}$ & $\begin{array}{l}\text { 1.North-West } \\
\text { Germany } \\
\text { 2.England } \\
\text { 3.Cologne }\end{array}$ & $\begin{array}{l}\text { Banker and } \\
\text { international trader }\end{array}$ & $\mathrm{N}$ & & $O D N B$ \\
\hline $\begin{array}{l}\text { William Littlebury (alias } \\
\text { Horn) } \\
\text { Fifteenth century }\end{array}$ & London & Salter & $\mathrm{Y}$ & & Kingsford \\
\hline $\begin{array}{l}\text { John Lovekyn } \\
\text { d. } 1368\end{array}$ & $\begin{array}{l}\text { 1.Kingston- } \\
\text { upon-Thames } \\
\text { Surrey } \\
\text { 2.London }\end{array}$ & $\begin{array}{l}\text { Stock } \\
\text { fishmonger; } \\
\text { Pepperer; Draper }\end{array}$ & $\mathrm{Y}$ & $\mathrm{Y}$ & $\begin{array}{l}\text { ODNB; Sharpe, Wills: } \\
\text { Part } 2\end{array}$ \\
\hline $\begin{array}{l}\text { John Maunche } \\
\text { d. } 1465\end{array}$ & $\begin{array}{l}\text { 1.Venice } \\
\text { 2.London }\end{array}$ & Distributor of imports & $\mathrm{N}$ & & $O D N B$ \\
\hline $\begin{array}{l}\text { Matilda Penne } \\
\text { d. } 1392 / 3\end{array}$ & London & Widow of skinner & $\mathrm{N}$ & $\mathrm{N}$ & $O D N B$; Veale \\
\hline $\begin{array}{l}\text { John Philipot } \\
\text { d. } 1384\end{array}$ & London & $\begin{array}{l}\text { Wool exporter and } \\
\text { mercer }\end{array}$ & $\mathrm{Y}$ & $\mathrm{Y}$ & $O D N B$ \\
\hline $\begin{array}{l}\text { Thomas Pope } \\
\text { d. } 1400\end{array}$ & Gloucester & $\begin{array}{l}\text { Import and export } \\
\text { trader via Bristol }\end{array}$ & $\mathrm{Y}$ & & $H P$ \\
\hline $\begin{array}{l}\text { John Pulteney } \\
\text { d. } 1349\end{array}$ & $\begin{array}{l}\text { 1.Leicester-shire } \\
\text { 2.London }\end{array}$ & Merchant & $\mathrm{Y}$ & $\mathrm{Y}$ & $O D N B$ \\
\hline $\begin{array}{l}\text { John Pyel } \\
\text { c. } 1315-1382\end{array}$ & $\begin{array}{l}\text { 1.Irthling- } \\
\text { borough, } \\
\text { Northants } \\
\text { 2.London }\end{array}$ & Merchant & $\mathrm{Y}$ & $\mathrm{Y}$ & $\begin{array}{l}\text { ODNB; O’Connor; } \\
H P\end{array}$ \\
\hline $\begin{array}{l}\text { Richard Russell } \\
\text { d. } 1435\end{array}$ & $\begin{array}{l}\text { 1.Durham } \\
\text { 2.York }\end{array}$ & $\begin{array}{l}\text { Vintner and wool } \\
\text { trader }\end{array}$ & $\mathrm{Y}$ & $\mathrm{Y}$ & HP; Alsford "Pious" \\
\hline $\begin{array}{l}\text { Isabelle Sayer } \\
\text { d. } 1473\end{array}$ & London & Silkwoman & $\mathrm{N}$ & & $O D N B$ \\
\hline $\begin{array}{l}\text { William Sevenoak } \\
\text { d. } 1432\end{array}$ & $\begin{array}{l}\text { 1.Kent } \\
\text { 2.London }\end{array}$ & Grocer & $\mathrm{Y}$ & $\mathrm{N}$ & $\begin{array}{l}O D N B ; \quad H P ; \text { Heath: } \\
\text { 213-21. }\end{array}$ \\
\hline $\begin{array}{l}\text { William Soper } \\
\text { Pre 1410-1458/9 }\end{array}$ & $\begin{array}{l}\text { 1.Winchester } \\
\text { 2.Southampton }\end{array}$ & $\begin{array}{l}\text { Wine importer and } \\
\text { ship owner }\end{array}$ & $\mathrm{Y}$ & $\mathrm{N}$ & $\begin{array}{l}O D N B ; H P ; \text { Alsford, } \\
\text { "Southampton" }\end{array}$ \\
\hline $\begin{array}{l}\text { Thomas Spring I } \\
\text { d. } 1440\end{array}$ & $\begin{array}{l}\text { Lavenham, } \\
\text { Suffolk }\end{array}$ & Clothier & & $\mathrm{Y}$ & $O D N B$ \\
\hline $\begin{array}{l}\text { Thomas Spring II } \\
\text { d. } 1486\end{array}$ & $\begin{array}{l}\text { Lavenham, } \\
\text { Suffolk }\end{array}$ & Clothier & & $\mathrm{Y}$ & $O D N B$ \\
\hline $\begin{array}{l}\text { John Tame } \\
\text { c. } 1430-1500\end{array}$ & $\begin{array}{l}\text { 1.Fairford, } \\
\text { Gloucester- } \\
\text { shire } \\
\text { 2.Cirencester } \\
\text { 3.London }\end{array}$ & Wool merchant & & $\mathrm{Y}$ & Herbert; Munn \\
\hline $\begin{array}{l}\text { Henry Tangmere } \\
\text { d. } 1361\end{array}$ & Cambridge & $\begin{array}{l}\text { Metal trader and } \\
\text { money trader }\end{array}$ & & & Cooper; Roach \\
\hline $\begin{array}{l}\text { William de Thorneye } \\
\text { d. c. } 1349\end{array}$ & $\begin{array}{l}\text { 1. Whaplode, } \\
\text { Lincolnshire } \\
\text { 2.London }\end{array}$ & Pepperer & $\mathrm{N}$ & $\mathrm{Y}$ & $\begin{array}{l}\text { Sharpe, Wills: Part 1; } \\
\text { Salzman }\end{array}$ \\
\hline
\end{tabular}




\begin{tabular}{|c|c|c|c|c|c|}
\hline $\begin{array}{l}\text { Roger Thornton } \\
\text { d. } 1430\end{array}$ & $\begin{array}{l}\text { 1.Witton, } \\
\text { Northumber- } \\
\text { land } \\
\text { 2.Newcastle- } \\
\text { upon-Tyne }\end{array}$ & Merchant & $\mathrm{Y}$ & $\mathrm{Y}$ & $\begin{array}{l}H P ; \quad \text { Hodgson; } \\
\text { MacKenzie; Maxwell } \\
\text { Lyte. }\end{array}$ \\
\hline $\begin{array}{l}\text { Henry Waleys } \\
\text { d. } 1302\end{array}$ & $\begin{array}{l}\text { 1.Chepstow, } \\
\text { Monmouth } \\
\text { shire } \\
\text { 2.London }\end{array}$ & Vintner & $\mathrm{Y}$ & $\mathrm{Y}$ & $O D N B$ \\
\hline $\begin{array}{l}\text { William Walworth } \\
\text { d. } 1386 ?\end{array}$ & London & Fishmonger & $\mathrm{Y}$ & $\mathrm{N}$ & $O D N B$ \\
\hline $\begin{array}{l}\text { John Welles III } \\
\text { d. } 1442\end{array}$ & $\begin{array}{l}\text { 1.Norwich } \\
\text { 2.London }\end{array}$ & Merchant and banker & $\mathrm{Y}$ & $\mathrm{Y}$ & $\begin{array}{l}H P ; \text { Heath: 213-3; } \\
\text { Alsford, "Wills" }\end{array}$ \\
\hline $\begin{array}{l}\text { Richard Whittington } \\
\text { c. } 1350-1423\end{array}$ & $\begin{array}{l}\text { 1.Pauntley, } \\
\text { Gloucster- } \\
\text { shire } \\
\text { 2.London }\end{array}$ & $\begin{array}{l}\text { Mercer and money } \\
\text { lender }\end{array}$ & $\mathrm{Y}$ & $\mathrm{N}$ & $\begin{array}{l}O D N B ; H P ; \text { Alsford, } \\
\text { "Whittington" }\end{array}$ \\
\hline $\begin{array}{l}\text { William Wilford } \\
\text { d. } 1413\end{array}$ & Exeter & Merchant & $\mathrm{Y}$ & $\mathrm{Y}$ & $O D N B ; H P$ \\
\hline
\end{tabular}

Notes:

Civic office holder=mayor, sheriff, recorder, alderman or bailiff

$O D N B=$ Oxford Dictionary of National Biography

$H P=$ History of Parliament

Crittall=Elizabeth Crittall, ed., A History of the County of Wiltshire: Volume 6 (London, 1962).

Furnivall=Frederick J. Furnivall, ed., The Fifty Earliest English Wills in the Court of Probate, London (London, 1882).

Kingsford= C. L. Kingsford, ed., John Stow A Survey of London: Reprinted From the Text of 1603 (Oxford, 1908). Roach=J. P. C Roach ed. A History of the County of Cambridge and the Isle of Ely: Volume 3 (London, 1959). Blank cell means no information available. Thomas Spring I and II do not appear in the ODNB using our search terms.

Sources: See table. 


\section{Table 1 \\ Categories of giving}

\begin{tabular}{|l|l|}
\hline $\begin{array}{l}\text { Municipal } \\
\text { improvements }\end{array}$ & $\begin{array}{l}\text { Building, improvement, maintenance and repair of streets, bridges, town walls, town gates; } \\
\text { wells; water fountains; water conduits, grain stores, market buildings, prisons; public } \\
\text { lavatories; harbour cranes; boundary markers; river dredging, embankment, and diversion; } \\
\text { donations towards 'common profit' of the town; local famine relief; loan chests for citizens }\end{array}$ \\
\hline Religion & $\begin{array}{l}\text { Foundation and financial support of religious orders or religious houses; building, } \\
\text { construction, maintenance and repair of churches; cancelling of debts to a religious house. } \\
\text { Excludes prayers for the soul of the donor that do not benefit the wider community }\end{array}$ \\
\hline Hospitals & $\begin{array}{l}\text { Foundation and financial support of hospitals; sponsorship of medical facilities, e.g. beds, } \\
\text { clothing; support for lepers, and for the sick }\end{array}$ \\
\hline Education & $\begin{array}{l}\text { Loan chests and scholarships for students; places at university; foundation and support of } \\
\text { libraries, colleges, and schools. }\end{array}$ \\
\hline Almshouses & Foundation and financial support of almshouses \\
\hline The poor & Support for the poor, both individually and collectively, either through gifts or facilities \\
\hline The young & Gifts for maidens, and for young people in poverty \\
\hline $\begin{array}{l}\text { Relief } \\
\text { prisoners }\end{array}$ & $\begin{array}{l}\text { Payments and other gifts to prisoners; money to prisons; improvements to the care of } \\
\text { prisoners }\end{array}$ \\
\hline $\begin{array}{l}\text { Support } \\
\text { employees }\end{array}$ & Support for workers, apprentices and servants \\
\hline $\begin{array}{l}\text { Social } \\
\text { rehabilitation }\end{array}$ & $\begin{array}{l}\text { Support and reform for prostitutes, the destitute, criminals, and debtors; discharge of debts } \\
\text { for imprisoned debtors }\end{array}$ \\
\hline $\begin{array}{l}\text { Charity } \\
\text { generally }\end{array}$ & Unspecified support for 'charity' \\
\hline
\end{tabular}

Table 2

Alternative uses of funds

\begin{tabular}{|l|l|}
\hline Category & Examples \\
\hline Family bequests & $\begin{array}{l}\text { Leaving wealth for daughter's dowry, widow's maintenance, younger sons to enter a } \\
\text { profession }\end{array}$ \\
\hline Lending at interest & Investing in friend's business schemes, developing a merchant banking business, \\
\hline $\begin{array}{l}\text { Residential } \\
\text { improvements }\end{array}$ & Building a new house or extending an existing one, creating a property portfolio \\
\hline Political influence & $\begin{array}{l}\text { Seeking political advancement at court or in the county (sheriff) through acquisition of } \\
\text { large landed estates, provision of lavish entertainment, or other conspicuous } \\
\text { consumption }\end{array}$ \\
\hline Business gamble & $\begin{array}{l}\text { Taking big business gamble that potential rivals lack the financial resources to } \\
\text { undertake (e.g. financing speculative voyages of discovery; participation in customs } \\
\text { syndicates) }\end{array}$ \\
\hline Pleasure & Gambling for amusement, sports, keeping mistresses \\
\hline
\end{tabular}


Table 3

Comparison by occupation in the Oxford Dictionary of National Biography

\begin{tabular}{|l|l|l|l|l|}
\hline Occupation & Total & Philanthropic & Non philanthropic & $\begin{array}{l}\text { Percentage } \\
\text { philanthropic }\end{array}$ \\
\hline $\begin{array}{l}\text { Entrepreneur } \\
\text { (using search term } \\
\text { entrepreneur or } \\
\text { merchant or trader) }\end{array}$ & 71 & 28 & 43 & $39 \%$ \\
\hline Lawyer & 52 & 10 & 42 & $19 \%$ \\
\hline Administrator & 167 & 38 & 129 & $23 \%$ \\
\hline Gentry & 49 families & 11 families & 38 families & $22 \%$ \\
\hline All 4 occupations & 339 & 87 & 252 & $26 \%$ \\
\hline
\end{tabular}

Table 4

Locations of entrepreneurial activity

\begin{tabular}{|c|c|c|c|}
\hline \multirow{2}{*}{$\begin{array}{l}\text { Place of birth or } \\
\text { early career }\end{array}$} & \multicolumn{3}{|c|}{ Place of main career before death } \\
\hline & London & Provincial town & ROW TOTAL \\
\hline London & London 'stayers' $=10$ & London leavers $=0$ & $\begin{array}{l}\text { Total originating in } \\
\text { London }=10\end{array}$ \\
\hline Provincial town & $\begin{array}{lll}\text { Provincial } & \text { movers } & \text { to } \\
\text { London }=15 & & \end{array}$ & $\begin{array}{l}\text { Provincial 'stayers' }=12 \\
\text { Movers between provincial } \\
\text { towns }=4\end{array}$ & $\begin{array}{l}\text { Total originating in the } \\
\text { provinces }=31\end{array}$ \\
\hline Overseas & London immigrants $=3$ & Provincial immigrants $=0$ & $\begin{array}{l}\text { Total immigrants from } \\
\text { overseas }=3\end{array}$ \\
\hline $\begin{array}{l}\text { COLUMN } \\
\text { TOTAL }\end{array}$ & $\begin{array}{l}\text { Total of London-based } \\
\text { entrepreneurs }=28\end{array}$ & $\begin{array}{l}\text { Total of provincial based } \\
\text { entrepreneurs }=16\end{array}$ & $\begin{array}{lr}\text { Total number of } \\
\text { entrepreneurs }=44\end{array}$ \\
\hline
\end{tabular}


Table 5

Factors in philanthropy

\begin{tabular}{|l|l|l|}
\hline $\begin{array}{l}\text { Factors } \\
\text { (not mutually exclusive) }\end{array}$ & Number of cases & $\begin{array}{l}\text { Percentage of all } 44 \\
\text { entrepreneurs }\end{array}$ \\
\hline No children & 9 & $20 \%$ \\
\hline Inheritance from wife & 4 & $9 \%$ \\
\hline Other identified inheritance & 5 & $11 \%$ \\
\hline Civic office-holder & 29 & $66 \%$ \\
\hline
\end{tabular}

Table 6

Alternative uses of wealth by philanthropic individuals or families

\begin{tabular}{|c|c|c|c|c|c|c|c|c|}
\hline & $\begin{array}{l}\text { Number of } \\
\text { people } \\
\text { who use } \\
\text { wealth in } \\
\text { alternative } \\
\text { ways }\end{array}$ & $\begin{array}{l}\text { Family } \\
\text { bequests }\end{array}$ & $\begin{array}{l}\text { Lending } \\
\text { out at } \\
\text { interest }\end{array}$ & $\begin{array}{l}\text { Residential } \\
\text { improvements }\end{array}$ & $\begin{array}{l}\text { Political } \\
\text { influence }\end{array}$ & $\begin{array}{l}\text { Business } \\
\text { gamble }\end{array}$ & Pleasure & $\begin{array}{l}\text { Total } \\
\text { number of } \\
\text { alternative } \\
\text { uses }\end{array}$ \\
\hline $\begin{array}{l}\text { All } \\
\text { philanthropic } \\
\text { entrepreneurs }\end{array}$ & 29 & $\begin{array}{l}14 \\
(29 \%)\end{array}$ & $6(13 \%)$ & $16(35 \%)$ & $8(17 \%)$ & $2(4 \%)$ & $0(0 \%)$ & 46 \\
\hline $\begin{array}{l}\text { ODNB } \\
\text { philanthropic } \\
\text { entrepreneurs }\end{array}$ & 21 & $9(27 \%)$ & $4(12 \%)$ & $12(36 \%)$ & $6(18 \%)$ & $2(6 \%)$ & $0(0 \%)$ & 33 \\
\hline $\begin{array}{l}\text { ODNB non- } \\
\text { philanthropic } \\
\text { entrepreneurs }\end{array}$ & 29 & $4(9 \%)$ & $\begin{array}{l}13 \\
(28 \%)\end{array}$ & $14(30 \%)$ & $8(17 \%)$ & $8(17 \%)$ & $0(0 \%)$ & 47 \\
\hline $\begin{array}{l}\text { ODNB } \\
\text { lawyers }\end{array}$ & 7 & $3(30 \%)$ & $0(0 \%)$ & $1(10 \%)$ & $5(50 \%)$ & $0(0 \%)$ & $1(10 \%)$ & 10 \\
\hline $\begin{array}{l}\text { ODNB } \\
\text { administrators }\end{array}$ & 23 & $\begin{array}{l}10 \\
(33 \%)\end{array}$ & $0(0 \%)$ & $11(37 \%)$ & $9(30 \%)$ & $0(0 \%)$ & $0(0 \%)$ & 30 \\
\hline ODNB gentry & 7 & $1(13 \%)$ & $0(0 \%)$ & $3(38 \%)$ & $4(50 \%)$ & $0(0 \%)$ & $0(0 \%)$ & 8 \\
\hline Total & 87 & 27 & 17 & 41 & 32 & 10 & 1 & 128 \\
\hline
\end{tabular}

